\title{
Human potential and the system of its commercialization management
}

\author{
Tetiana Shkoda ${ }^{1, *}$, Iuliia Gernego ${ }^{1, * *}$, Mariia Tepliuk ${ }^{1, * * *}$, and Anastasia Stefanita ${ }^{2, * * * *}$ \\ ${ }^{1}$ Kyiv National Economic University named after Vadym Hetman, 54/1 Peremohy Ave., Kyiv, 03057, Ukraine \\ ${ }^{2}$ Academy of Public Administration, 100 Ialoveni Str., Chisinau, MD 2070, Moldova
}

\begin{abstract}
The important factor of business sustainability is human capital. In this regard, there is need to estimate human potential, concerning the effectiveness of its management and commercialization probability. The current research problem lays upon the human potential management and the possibility of its commercialization. The paper aims to provide scientific support on human potential and human capital theories, concerning their connection within the system of a sustainable business development. The research methodology is based on theoretical and methodological approaches of Ukrainian and foreign experts from the last ten years, reflecting human capital and human potential concepts, taking into account business needs. The main part of research highlights the special status of human potential, based on its specific characteristics, including network effects, the ability to convert human potential benefits into significant social and economic effects, hybrid and multiplicative. The paper proposes a new methodological approach on technology for human potential commercialization and management. Human potential commercialization measurement is offered as a new model to assess the significance of human potential and its managerial effectiveness estimation. The study results can be used within programs for sustainable and social business development. More extensive study is required to prove the proposed methodological approach effectiveness within different sectors and branches.
\end{abstract}

\section{Introduction}

\subsection{Research question}

Nowadays, our society is under the influence of innovation processes, which require its transformation into an information society. Thereby, the process of added value formation is based on specific information and knowledge resources, created by human beings. The human capital formation, development and management, along with innovative transformations and human potential support, are playing the strategically decisive role in ensuring economic stabilization and social welfare.

The human development has received increased attention across a number of researches in recent years, because traditional economic concepts based on obtaining the maximum possible benefits from limited resources, including natural resources, labor and capital, are losing relevance.

One of the most significant current discussions in social and economic sciences concerns social progress as one of the main objectives and driver of post-industrial society growth. In particular, the enhancement of human potential is deeply connected with competitive business development, causing a high level of social and economic development. On the one hand, the rich human potential creates the basis for dynamic growth and rapid business development [1], providing a basis for high competitiveness and

\footnotetext{
*e-mail: shkoda-tetiana@kneu.edu.ua

**e-mail: iuliiagern@ukr.net

***e-mail: mteplyuk@gmail.com

****e-mail: iuliia88iuliia@gmail.com
}

further growth. On the other hand, the successful and sustainable business creates the framework for the systematic reproduction, promoting the positive dynamics of human development. This shows the availability of a system of direct and inverse relationships between human development and business profitability.

Thereby, currently, successful business faces an urgent need to increase its human resources along with more traditional material, financial, informational resources etc. The above-mentioned combination has a pivotal role in accomplishing the mission and strategic objectives around which its entire activity revolves.

Thereby, to appreciate a business in an appropriate way and its potential for further development, there is a need to estimate its human, material, financial, and other potential. Evidence suggests that the growing production capacity of business is possible in case of using efficiently all means of production that it possesses. Although technical progress has substantially reduced human presence in a measure of production processes, no economic process has been noticed at any stage in the evolution of humanity that can replace by human contribution. Thereby, human potential involvement becomes more substantial, providing an important requirement to meet diverse economic and social needs.

Thereby, the key factor of sustainable development of a modern enterprise is not only the modernization of its own production and updating of the scientific and technical base, but also the increase of competitiveness. The search for ways to effectively develop the human capital 
of the organization is directly related to the management quality. This is becoming especially important in the context of the systemic social and economic crisis that is observed in globally and in our country nowadays. This requires fast decision-making, flexibility, efficiency in the enterprise. Consolidation of resources and clear become fundamentally important performing management functions of the organization, which directly depend on the quality policy of capitalization of all available organizational resources.

In light of recent trends of sustainable human development, it is rather difficult to find studies that provide a comparative analysis of indicators of both human potential and the system of its commercialization management. Thus, the current study tends to highlight the tendencies of human potential development within innovative society, considering also its systematic management at business level. The genesis of this thesis can be traced back to the time the authors became interested in human capital and development, including methodological approach to their estimation.

\subsection{Previous researches}

Several previous studies and international organizations reports have found that human potential plays a significant role in building business capacity and competitiveness both at the national level and globally.

A number of cross-sectional studies proved the existence of the concept of human development [2,3].

There are numerous and varied approaches to provide human potential definition. The conceptual studies of human potential are represented both at the macro and micro level. In accordance with the topic of current study, the human potential concept is considered at the microeconomic level. This contains the dynamic factor, representing working capacity, knowledge and potential for further development. The study of the human resources at microeconomic level, conducted by Isaic-Maniu et al., reflects labour as an active production factor. Thereby, to characterize labour, the researchers define necessity to highlight the following aspects, namely: volume, structure, dynamics, movement and use of labour [4].

However, there are also another points of view on human potential essence and its managerial capacity. For instance, the authors of the paper on entrepreneur strategies consider the human potential as presentation of the total number of employees that the company needs in order to carry out its activities. The employees are considered as a common factor, which has considerable impact on enterprise development. At the same time, human potential also includes other members outside the unit, which through the board of directors, consultants or other forms use a part of the time budget for works and actions in the interest of the respective organizations [5].

There is also a growing body of literature that recognizes the importance of the following aspects analysis, including: the size and structure of human resources as the basis for an appropriate potential formation; the analysis of human resource behavior as the static factor of human potential development; analyzing the efficiency of human resource growth and utilization as the dynamic factor of human potential development. The above-mentioned aspects are considered at the microeconomic level [6].

Understanding the complexity of human potential causes the widespread of researches on its main components, including the use of knowledge and working capacity. For instance, the fundamental concept of knowledge use was considered by Hayek [7]. Machlup also studied human potential to show the particular importance of information and knowledge [8]. Shumpeter defined human potential in the context of business development and entrepreneur capacity growth [9]. Bell has examined the role of human potential within post-industrial society [10]. Several studies of Porter have documented the influence of human potential on social responsible business strategies and its competitive advantages [11]. Existing research by Castells recognizes the critical role played by human development and potential in our information age [12].

A considerable amount of literature has been published on fundamental aspects of attracting investment for human development and potential [13]. In particular, such aspects are considered within particular human development and potential concepts. Factors found to be influencing human capital and human potential development have been explored in several studies by Becker [14]. Data from several studies of Mincer suggest that investment in human capital plays a significant role in income formation [15]. Results from studies of Schultz demonstrate a strong and consistent association between investment in human potential and social sector development [16]. Several attempts have been made by Sharp to consider human potential as one of important object for investment activity [17].

Experts from international and regional organizations have made a significant contribution to the research and development of a new paradigm of sustainable human development and human potential. In particular, some parts of above-identified problems have been reflected in: UN programs [18] and reports (Transformation of our world: Sustainable Development Agenda 2030 [19]; World Investment Report 2017 [20]); NATO (The Shared Perspective of the World in 2030 and Beyond: Themes and Drivers [21]; Multiple futures project - Navigating towards 2030 [22]); World Business Council for Sustainable Development (WBCSD) (Vision-2050. The new agenda for business.

The above-mentioned researches mostly consider the nature of human development and human potential and their influence on social and economic development. However, there is still a rather little published researches on possibility to combine the peculiarities of human potential and studies on system of human potential management. Thus, the chosen problem is of a significant scientific interest nowadays.

\subsection{The scientific problem}

The scientific problem of this article lays upon the human potential as a driver of sustainable economy development, 
concerning methodology on human potential commercialization management. The hypothesis of the paper has both theoretical and applied background, concerning the systematic approach on human potential management, appearing both in theoretical concepts and sustainable business. This aims to activate sustainable human development both at business and national levels.

The aim of the current study is to identify the social (human development) dimension of building a systematic approach to sustainable business process management. The aim is specified in the form of tasks, including the theoretical foundations of human potential concept, providing theoretical and applied framework in human potential commercialization management, assessment of existing experience and opportunities for further implementation of human potential commercialization management ideas in the context of social responsible business and sustainable national economy.

The object of the research is the human potential boost for business activity that provide basis for its sustainable development.

The subject is human potential commercialization management, contributing the social and economic growth of business, national economy and their global competitiveness.

\subsection{The research methodology}

The research methodology is based on foreign and Ukrainian scientific literature and statistical data analysis (within the last ten years) to show a link between human potential and effectiveness of its commercialization management. The primary data of international and Ukrainian social responsible business development reports within the last five years are reproduced to confirm appropriate human potential trends. The methods of economic and mathematic modelling and dynamics are used to consider human potential effectiveness and its commercial nature. A combination of quantitative and qualitative approaches was used in the innovative methodology of building the system of human potential commercialization analysis. In particular, the theoretical framework of human potential commercialization system is based on management technologies. The possibility of the system application is considered upon its beneficiaries' requirements. This provides robust evidence for consideration of human potential commercialization management as a driver of sustainable business development.

The scientific novelty of the methodology is as follows: despite a large number of foreign and domestic approaches to the measurement of human capital as a criterion of its management, the issues of its measurement are incomplete, the indicators are contradictory, and therefore requires further elaboration in order to create a universal and integrated model. This research proposes a new methodology to provide the system of human potential commercialization management.

Both the human potential development indicators and indicators of its commercialization management are presented. On the one hand, this provides opportunity to de- fine the role of human potential for business development. On the other hand, this allows to estimate the possibility to increase human potential by sustainable business entities.

\subsection{The current research structure}

The current research consists of the following parts:

- primarily, the theoretical and methodological framework based on human potential concept and its managerial background is considered;

- then, the distribution of institutions by levels of human potential formation and commercialization is proposed;

- finally, the research conclusions on the value of commercialized human potential are provided.

The research practical implication is that results can be used within business strategies and sustainable development models to accept social and economic challenges both on business and national levels.

\section{Main theoretical and methodological assumptions of the research}

\subsection{The conceptual framework of human potential sustainability}

The widespread of human potential ideas within the works of economists, as well as the relevant processes practical implementation caused the necessity to build an appropriate conceptual framework, considering the possible sustainability and commercialization.

Sustainability is a manifestation of the state of a phenomenon or process, which presupposes the existence of equilibrium over a long period of time. At the same time, sustainability is a manifestation of the result of the interaction of elements or certain components of the object. Therefore, it is logical to assume that the basis of balancing a particular system are internal (endogenous) factors. Accordingly, changes in parameters of sustainability under the influence of destructive exogenous factors can be counteracted by strengthening the system from the inside. Sustainability is a systemic manifestation of a phenomenon or process that reflects the ability of the research object to function in conditions of external and internal influences $[2,23]$.

At the same time, the probability of human potential commercialization concerns meaning and manifestation of "human development", "human growth" and "human progress". The term "growth" is associated with the indicator of national income per capita, the transition from lower to higher quality. At the same time, "development" is broader, because it involves covering various aspects of the change process. In the context of human potential, attention should be paid to the level of health and education, quality of work and social stability, changes in the environment. Development is defined as the process during which changes occur, the transition from one state to another, more perfect; transition from the old qualitative state to the new, from simple to complex, from lower to higher. 
The above-mentioned definition of development includes processes that improve the objects of research that may be associated with it [24]. "Progress" involves progressive development, and "modernization" characterizes the dynamic aspect of development, providing a kind of modifications (figure 1).

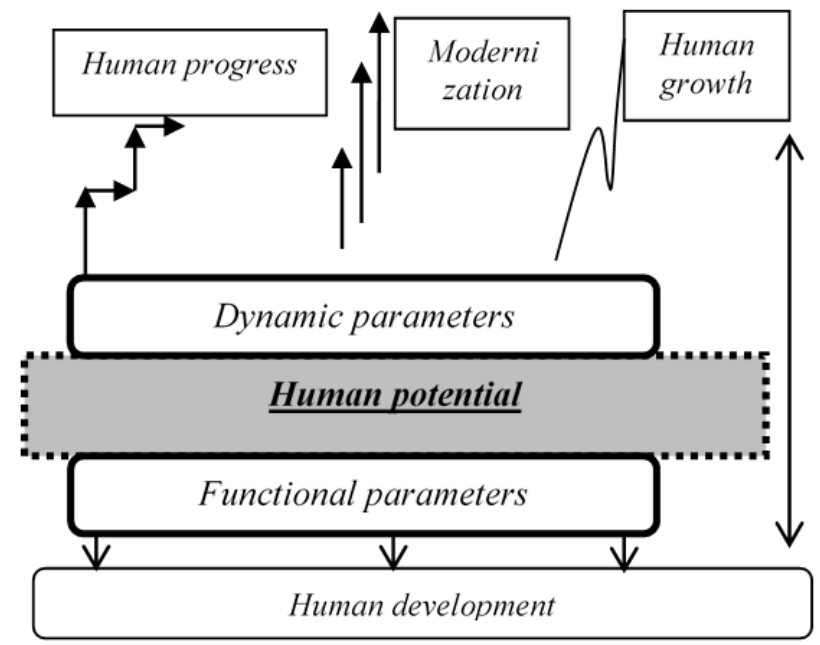

Figure 1. Schematic correlation of human potential parameters

The range of research on above-mentioned questions is reflected in the work of UNDP experts. The relevant analytical findings were primarily summarized in the Global Report on Human Development in 1990 [25].

According to UNDP experts, human potential considers a process that allows people to make more choices. In principle, this choice is likely to be endless and will change over time. However, at all levels of development, key aspects of human potential create opportunities to live healthy lives, acquire knowledge and access the resources needed to ensure a decent standard of living. If such opportunities are not available, the person will not have access to other opportunities, concerning the possibilities of commercialization.

\subsection{The system of human potential management commercialization}

In the context of business management, the available practical experience indicates the need to provide mandatory procedures for the commercialization of human potential and its transformation into human capital as a newly created added value. This may also be confirmed by the results of a sociological study on the prospects for the commercialization of human potential.

Therefore, we propose to manage the commercialization of human potential in accordance with the technology shown within figure 2.

One of the important system-forming components in the organizational and economic mechanism of strategic management of human capital is the functional component of the management of commercialization of human potential (figure 3).
MANAGERIAL TECHNOLOGY OF HUMAN POTENTIAL COMMERCIALIZATION

Estimation of the value of commercialized human potential according to the developed methodologv

Implementation of the human resources commercialization management system 75

Application of the scheme of institutions responsible distribution for the commercialization of human potential

Figure 2. Technology for managing the commercialization of human potential

In our opinion, it is expedient to apply a systemsynergetic scientific approach to its construction. Its systemic component involves the use of a set of organizational structures, forms and methods of management, legal norms that allow the implementation of economic laws and the process of commercialization of human potential.

The implementation of the system-synergetic approach requires the establishment of links between the components in the organizational and economic mechanism of human capital strategic management, which provides the coordinated interaction of the main subsystems, namely:

- the control subsystem provides expertise on a resonant managerial influence according to the goals and principles of operation, as it is the subject of management, which is the most mobile and flexible element of the system. The supporting subsystem is also included in the framework of the control subsystem, within which the normative-legal, information-methodical and methodological support is carried out;

- managed subsystem is a managerial object that implements organizational and managerial, economic and socio-psychological relations. A regulatory-analytical subsystem is also included in the managed subsystem, which establishes a correspondence between the goals and results for the implementation of feedback between the subsystems.

Supply and regulatory and analytical subsystems are tools for the influence of the control subsystem on the managed subsystem. This provides a distinction between internal mechanisms of integrity and mechanisms of interaction with the external environment. At the same time, the inverse effect of the controlled subsystem on the control subsystem in the form of transmission of certain information. 


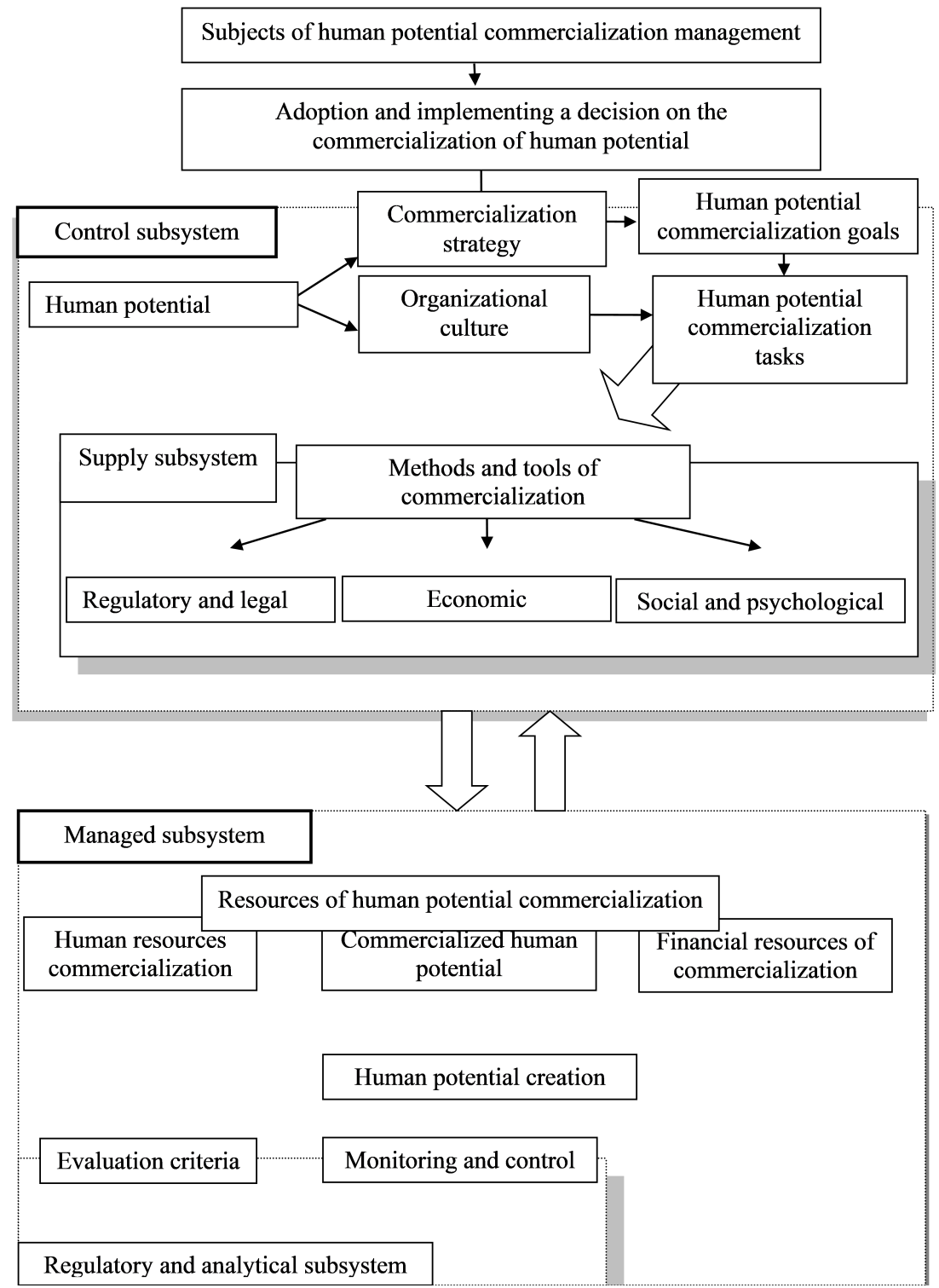

Figure 3. System for commercialization of human potential management

\section{Research results}

\subsection{The conceptual framework of human potential sustainability}

Determining the connection between human capital and human potential is an important practical aspect for business development, considering its competitiveness and sustainable development at regional and national levels (figure 4).

The element-by-element division of human potential and human capital created the possibility to be carried out on the basis of institutional economic theory. The theoretical background of this part of research lays in works of such Ukrainian scientists as Grishnova [26], who associates human capital at the microeconomic level with the production and commercial capital of the enterprise, as the source of profit is all types of capital; and Nikolaichuk [27], who considers the problem of human potential commercialization, its conversion into the human capital.
The problem of the relationship between the owner and the exploiter of human capital is both important for researchers and practical application within business entities.

Thereby, the human potential commercialization provides the boost for personal development, business effectiveness increase and national economy sustainability. Thus, there is a practical need of human potential commercialization measurement.

\subsection{Human potential commercialization measurement and its managerial effectiveness}

The strategic concepts of human potential development and human capital increase provide evidence that the result of the commercialization of human potential is human capital in the form of added value. In this case, a realistic relationship emerges, namely: the value added increase causes the higher intensity of human capital growth (figure 5). 


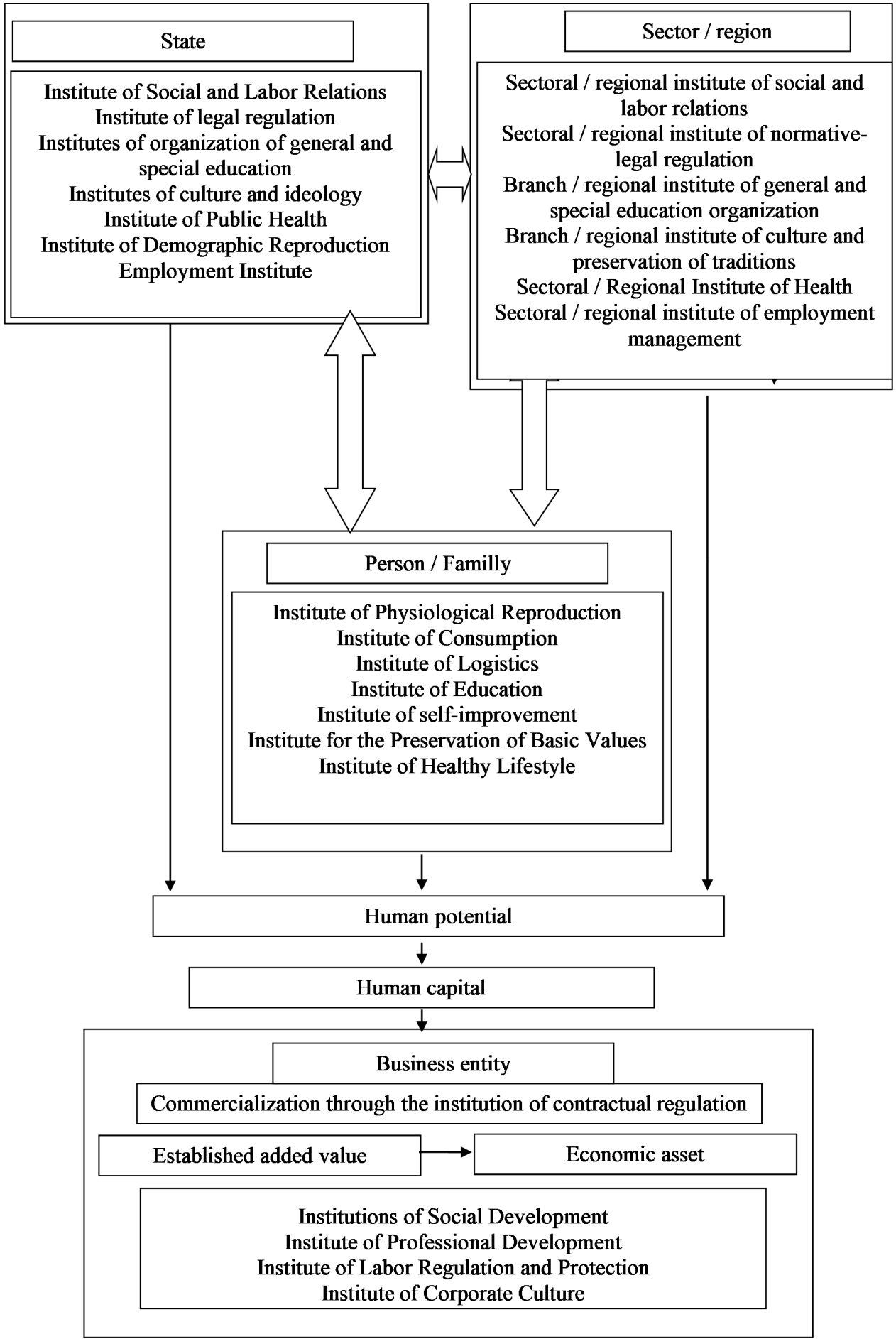

Figure 4. Distribution of institutions by levels of formation and commercialization of human potential

To calculate the value of commercialized human potential, it is necessary to use the technique of determining future value, based on the logic of complex interest (figure 5). This represents a geometric relationship between the initial cost of human potential suitable for commercial use, interest rate and accumulation period:

$$
F V_{c h p}=V_{c h p} *(1+r)^{n} .
$$

$F V_{c h p}$ - the future value of commercialized human potential;
$V_{c h p}$ - the initial cost of human potential suitable for commercial use;

$$
\begin{aligned}
& r \text {-interest rate or discount rate; } \\
& n-\text { the number of interest accrual periods. }
\end{aligned}
$$

To make the appropriate calculations according to the above-mentioned formula, it is necessary to determine the amount of human potential suitable for commercial use and the interest rate. It is proposed to calculate the initial cost of human resources suitable for commercial use, 


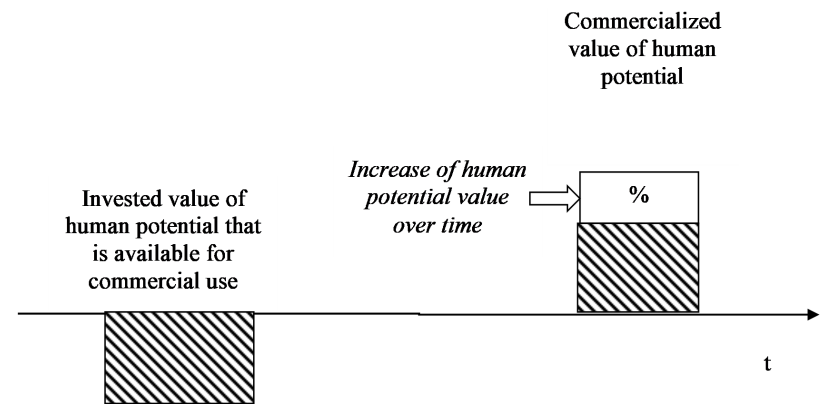

Figure 5. Increase in the principal amount of commercialized human potential as a share of human capital of employees hired during the last year

based on the use of the cost method according to the following algorithm:

\section{First stage}

The cost of developing human potential suitable for commercial use is determined:

$$
C_{c h p}=\left(C_{h P}+C_{\text {Person }}\right) *(1+(P / 100)) * K_{c f} .
$$

where $C_{h P}$ is the cost of developing human potential suitable for commercial use;

$C_{\text {Person }}$ - staff costs;

$P$ - labor profitability;

$K_{c f}$ - conversion factor, by which the time costs are reduced to a single point in time (adjusted costs for the value of the labor price index (wages) on the date of assessment. The coefficient should be determined by formula (3).

$$
K_{c f}=W_{m b} / W_{m s f e} .
$$

where $W_{m b}$ - an average monthly salary of full-time employees by enterprise / business segment;

$W_{m s}$ - the average monthly salary in the equivalent of full employment.

\section{Second stage}

The value of the coefficient is taken into account, considering the degree of frequency of human potential use $\left(K_{H p F}\right)$ that is suitable for commercial use during the first year of operation:

$$
K_{H p F}=1-\left(T_{A} / T_{N}\right) .
$$

where $T_{A}$ - actual working time fund;

$T_{N}$ - nominal fund of working time.

\section{Third stage}

The final cost of human potential suitable for commercial use is calculated in the following way:

$$
V_{c h p}=K_{c f} * K_{H p F} .
$$

The results of the authors' calculations according to the proposed algorithm at the example of air transport enterprises are represented in table 1 [28].
Based on the data of table 1, the authors should admit that the lower is labor profitability, then the higher is the amount of the cost of developing human potential suitable for commercial use. To determine the discount rate, it is proposed to adapt the formula of the weighted average cost of capital to the needs of our study [29]. The adaptation is possible on the basis that we determine the share of human capital of employees hired during the last year.

Thus, for the cash flow of all human capital, a discount rate is applied equal to the sum of weighted rates of return on equity and borrowed human capital, where the weight is the share of equity and borrowed human capital in the structure of human capital. This discount rate is called the weighted average cost of human capital (WACHC).

The weighted average cost of human capital is calculated by the following formula:

$$
\begin{array}{r}
W A C H C=k h c_{f t} \cdot\left(1-t_{w 1}\right) \cdot w h c_{f t}+ \\
+\left(k h c_{p t} \cdot\left(1-t_{w 2}\right) \cdot w h c_{p t}+k h c_{c} \cdot\left(1-t_{w 3}\right) \cdot w h c_{c}+\right. \\
\left.+k h c_{l} \cdot\left(1-t_{w 4}\right) \cdot w h c_{l}\right)
\end{array}
$$

where $k h c_{f t}$ - the cost of human capital;

$t_{w 1}$ - the amount of tax rates withheld from the salaries of key employees;

$w h c_{f t}$ - share of own human capital in the structure of human capital;

$k h c_{p t}$ - the cost of attracting human capital from external partners;

$t_{w 2}$ - the amount of tax rates withheld from the salaries of external part-timers;

$w h c_{p t}$ - specific share of attracted human capital of external part-timers;

$k h c_{c}$ - the cost of attracting borrowed human capital under civil law contracts;

$t_{w 2}$ - the amount of tax rates withheld from wages under civil law contracts;

$w h c_{c}$ - specific share of attracted human capital under civil law contracts in the structure of human capital;

$k h c_{l}$ - the cost of attracting borrowed human capital under leasing agreements;

$t_{w 3}$ - the average interest paid by the lessee to the lessor under leasing agreements;

$w h c_{l}$ - specific share of attracted human capital under leasing agreements.

In contrast to the classical formula of the weighted average cost of capital [29], in the proposed version of the formula for the weighted average cost of human capital, it is proposed to apply multipliers of tax rates withheld from the salaries of key employees, part-time employees and those working under civil law contracts. This multiplier is of great importance for the part of the attracted human capital, which works under leasing contracts, because there the lessee pays interest for the provision of leasing services to the lessor.

We believe that the scientific basis for the division of human capital into own and involved ones is the so-called "shamrock theory" of Charles Handy [30]. The scientist presented the organization in the form of a shamrock, the first leaf of which consists of key employees, the second 
Table 1. Calculations according to the proposed algorithm at the example of air transport enterprises

\begin{tabular}{|c|c|c|c|c|c|c|}
\hline \multirow{2}{*}{ Indicator } & \multicolumn{6}{|c|}{ Year } \\
\hline & 2013 & 2014 & 2015 & 2016 & 2017 & 2018 \\
\hline Net Income & 115056,8 & 61492,8 & 102152,9 & 73093,46 & 54303,81 & 35514,15 \\
\hline $\begin{array}{l}\text { Total average number of em- } \\
\text { ployees, persons }\end{array}$ & 14167 & 12731 & 13540 & 15789 & 16100 & 16410 \\
\hline $\begin{array}{l}\text { Total amount of labor costs, } \\
\text { thousand UAH }\end{array}$ & 268267,1 & 729970,4 & 389582,6 & 588721,58 & 646796,65 & 704871,73 \\
\hline $\begin{array}{l}\text { Total salary fund (full-time } \\
\text { and part-time employees) }\end{array}$ & 1217366,7 & 1065527,0 & 1561911,3 & 1699528,38 & 1827792,78 & 1956057,18 \\
\hline $\begin{array}{l}\text { Nominal fund of working time } \\
\left(T_{A}\right)\end{array}$ & 17491943 & 14133377 & 13461641 & 15437586 & 14085205 & 12732824 \\
\hline $\begin{array}{l}\text { Actual working time fund } \\
\left(T_{N}\right)\end{array}$ & 15277142 & 11874427 & 11530893 & 13095421 & 11864246 & 10633070 \\
\hline $\begin{array}{l}\text { Average monthly salary in } \\
\text { the equivalent of full employ- } \\
\text { ment, } \mathrm{UAH}\left(W_{m s}\right)\end{array}$ & 5205,23 & 7023,6 & 7655,69 & 8087,15 & 8762,29 & 9437,42 \\
\hline $\begin{array}{l}\text { Average monthly salary of } \\
\text { full-time employees by enter- } \\
\text { prise / business segment, UAH } \\
\left(W_{m b}\right)\end{array}$ & 4538,88 & 6393,9 & 6983,62 & 7319,68 & 7909,69 & 8499,71 \\
\hline$K_{c f}$ & 0,8720 & 0,9103 & 0,9122 & 0,9051 & 0,9027 & 0,9006 \\
\hline Labor profitability $(P)$ & 0,43 & 0,08 & 0,26 & 0,12 & 0,08 & 0,05 \\
\hline$K_{H p F}$ & 0,8734 & 0,8402 & 0,8566 & 0,8483 & 0,8423 & 0,8351 \\
\hline$C_{c h p}$ & 1301005,72 & 1635899,22 & 1784845,95 & 2073665,95 & 2235680,30 & 2397742,68 \\
\hline
\end{tabular}

- external contractors, and the third - temporary and parttime employees. Kravchenko refers to the attracted human capital that part of which is involved for performance of one-time or special works, and also - human capital of external part-timers [31].

Therefore, there is a need to apply the formulas of such indicators as equity and borrowed human capital. Thereby, the formula for calculating equity [32] will be adopted in the following way:

$$
B_{o w n_{H} C}=N I_{e} / p_{m}
$$

where $N I_{e}$ - the amount of net profit per employee;

$p_{m}-$ market price of one employee ${ }^{1}$.

It is proposed to calculate the amount of attracted human capital taking into account the number of employees working under civil law contracts and on lease terms.

Moreover, the proposed formula makes it possible to calculate the invested human capital, as well as to offer another option for calculating the economic value added of human capital. Today, the classical formula given by Fitzenz [33] makes it possible to determine how much economic added value of the organization accounts for the average amount of labor spent to obtain the result.

The return on assets of human capital can be calculated by the formula of the ratio of profit of the enterprise and invested human capital. This formula is very close to the formula of return on investment in human capital [34], which Zakharova defines through the ratio of net profit of the enterprise and the amount of funds that were invested

\footnotetext{
${ }^{1}$ under the market price of one employee, we mean the salary of one employee, the cost of hiring, training, etc.
}

in human capital for a certain period. However, the values for the calculation in both variants are different.

Thus, the economic added value of human capital is proposed to be calculated in the following way:

$$
E V A_{H C}=\left(P A_{H C}-C B_{H C}\right) * K_{H C}
$$

where $E V A_{H C}$ - economic added value of human capital;

$P A_{H C}$ - return on assets, human capital;

$C B_{H C}$ - invested human capital (asset value human capital).

Since we consider human capital as an asset of the enterprise, it is important to note that by European standards it belongs to intangible assets and includes: personal goodwill; skilled and assembled employees; lease agreements; favorable employment contracts; know-how, inseparable from the person [35].

In general, the established method of assessing human capital as a result of commercialization of human potential of the enterprise is considered one of the innovative approaches to the implementation of the sociocommercialization component of human capital of enterprises. It is proposed by the authors for practical implementation on the example of enterprises.

\subsection{Human potential of business development in Ukraine}

Social responsible business is considered as the business with the highest probability of human potential commercialization in Ukraine. In accordance with applied researches of Ukrainian analytics, the main driver for the corporate social development policy implementation is 
moral consideration and - according to representatives of the companies - the main barrier for non-implementation of the CSR policy is lack of financial resources, volatile political situation in the country, inadequate legal framework which would encourage this activity, and tax pressure [36].

However, $76 \%$ of business representatives are considering their social responsibility as the policy for development and improvement of conditions for staff. A rather significant part of companies concerns the reason of social responsibility as assistance for loyalty of staff increase (figure 6) [28, 36-39].

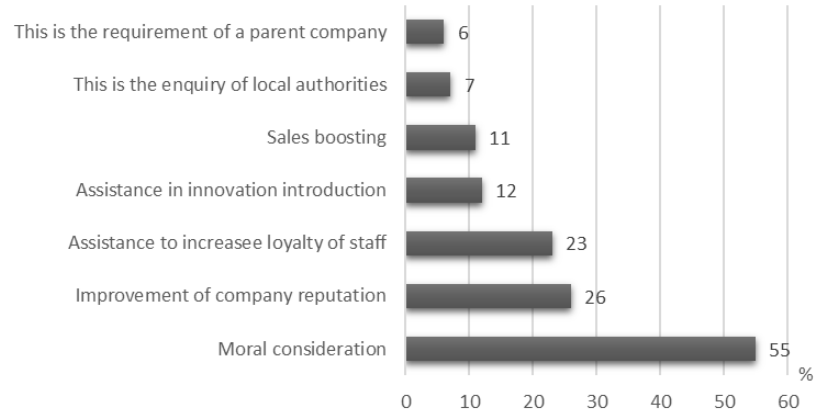

Figure 6. The reasons to develop the social responsible business

Almost half of the Ukrainian companies provide their employees with an opportunity to work under flexible working schedules and implement professional development programs. Salary rise, payment of declared salary and bonuses are also considered as social responsible practices, concerning labor relations (figure 7) [28, 36-39].

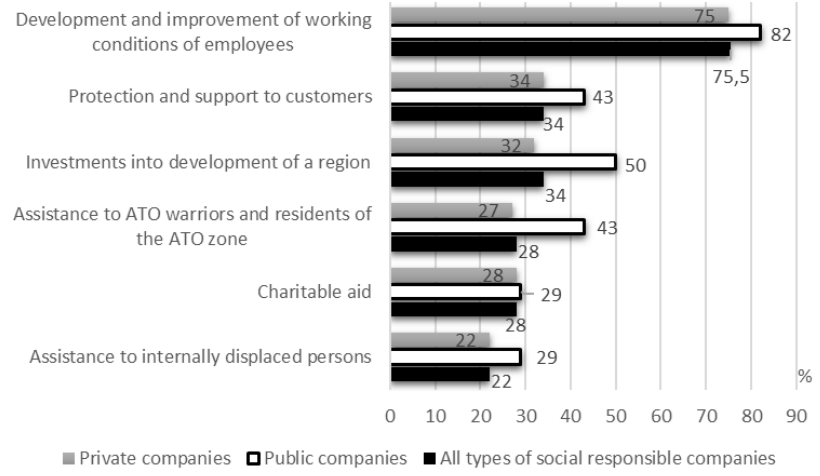

Figure 7. The meaning of social responsibility

This provides the background for human potential increase in our country, increasing also the probability of its commercialization.

\section{Conclusions}

Given all that has been mentioned so far, one may state that human potential is getting growing importance within business sustainable development. The primary analytical research of social responsible statistics shows the increasing trends of business staff support, increasing the probability of human potential commercialization.
At the same time, the study results show the lack of methodological basis on human potential and human capital research, considering a reflection of interrelations between them. Thereby, the commercialization criteria are chosen as the most appropriate for possible comparison. For measuring the concentration of efforts for increasing effectiveness of commercialized human potential, the theoretical basis should be appropriate for its practical implementation to increase business activity.

It has been conclusively shown that the effective management of the human potential cannot be achieved without establishing the effective use of the human resources and its appropriate measurement. A new approach of human potential measurement clarifies what indicators can be considered to precisely measure more accurate human capital. On the basis of the results of quantitate and qualitative methods analysis, it can be concluded that the weighted average cost of human capital is calculated taking into account the multipliers of tax rates withheld from the salaries of key employees, part-time employees and those working under civil law contracts. Collecting various quantitative and qualitative data will allow for better control and use of human potential, because the effective manager should know the whole potential of employees.

There is an urgent need to concentrate more efforts on the human potential commercialization by Ukrainian business. Thereby, the study results can be used by the business structures to provide managerial and financial support for human potential commercialization in part of the company staff support, stimulating its capacity growth.

In particular, the Ukrainian business stakeholders tend to pay attention on the following activities:

- stimulating the development of human potential and human capital, considering also their management and commercialization, in the works of Ukrainian scientists;

- creation of a centralized system of informing the national business entities and investors regarding the human potential development advantages;

- intensification of cooperation between public and private companies, who are ready to support human potential development both at business and national levels.

The essence of human potential is both applied and theoretical question. Despite there is already a measure of researches on human potential, experts still have a lack of information on some applied aspects, including:

- a measure of long-term results from human potential commercialization;

- lack of information on successful human potential and human capital development practises;

- lack of human capital and human potential statistic both at business and national levels.

Thereby, there is a need for further research, considering human potential commercialization and its practical implication within modern society. Thus, this is the subject for future researches. 


\section{References}

[1] T. Shkoda, M. Tepliuk, I. Riepina, I. SemenetsOrlova, O. Domina, Financial and Credit Activity: Problems of Theory and Practice 4, 522 (2020)

[2] M. Stavridou, S. Vangchuay, African Technology Development Forum Journal 9 (2017)

[3] T. Shkoda, Rynok pratsi ta zajniatist naselennia 1, 37 (2016)

[4] B. Ileanu, A. Isaic-Maniu, C. Herteliu, T. Andrei, Journal of Applied Quantitative Methods 10, 84 (2015)

[5] O. Nicolescu, C. Nicolescu, P. Truică, D. Urâtu, S. Corcodel, White Charter of SMEs (Sigma Publishing House, Bucharest, 2016)

[6] A. Skibiński, IBIMA Business Review 2019 (2019)

[7] W. Butos, Advances in Austrian Economics 13 (2010)

[8] F. Machlup, Knowledge: Its Creation, Distribution and Economic Significance, Volume I: Knowledge and Knowledge Production (Princeton University Press, Princeton, 2014)

[9] J. Schumpeter, in Joseph Alois Schumpeter: Entrepreneurship, Style and Vision, edited by J. Backhaus (Springer US, Boston, MA, 2003), pp. 5-59, ISBN 978-0-306-48082-9, https://doi .org/10. $1007 / 0-306-48082-4 \_2$

[10] D. Bell, D. Morrison-Love, D. Wooff, M. McLain, International Journal of Technology and Design Education 3 (2017)

[11] M. Porter, J. Heppelmann, Harvard Business Review (2017)

[12] K. Kirtiklis, Lingua Posnaniensis 59, 65 (2017)

[13] I. Gernego, O. Dyba, L. Petrenko, Financial and credit activity: problems of theory and practice $\mathbf{3}$ (2019)

[14] G.S. Becker, Human capital: A theoretical and empirical analysis, with special reference to education (University of Chicago press, 2009)

[15] B. Chiswick, J. Mincer, Review of Economics of the Household 1, 343 (2003)

[16] T. Schultz, Tech. rep., Center Discussion Paper, Yale University, Economic Growth Center, New Haven (1987)

[17] W. Sharpe, G. Alexander, J. Bailey, Investments (Prentice Hall, New Jersey, 1999)

[18] Human Development Report (2020), http://hdr.undp.org/en/content/ human-development-index-hdi

[19] Transforming our World: The 2030 Agenda for Sustainable Development (2015), https:// sustainabledevelopment.un.org/post2015/ transformingourworld/publication

[20] World Investment Report 2017 (2017), http: //unctad.org/en/PublicationsLibrary/ wir2017_en.pdf

[21] The shared perspective of the world in 2030 and beyond: Themes and drivers (2013), http://www .act . nato.int/images/stories/ events/2012/fc_ipr/sfa_ws2_rap.pdf

[22] Multiple futures project - Navigating towards 2030 (2010), http://www.act.nato.int/images/ stories/events/2009/mfp/20090503_MFP_ finalrep.pdf

[23] M. Dyba, I. Gernego, O. Dyba, A. Oliynyk, Management Theory and Studies for Rural Business and Infrastructure Development 42 (2020)

[24] P. Maskell, A. Malmberg, Cambridge Journal of Economics 23 (1999)

[25] Human Development Report 1990. Concept and Measurement of human development (1990), http://hdr. undp.org/en/reports/global/ hdr 1990/chapters/

[26] O. Grishnova, Social and Labour Relations: Theory and Practice 1, 34 (2014)

[27] M. Nikolaychuk, Human capital management in the conditions of knowledge economy development: problems of theory and practice (KhNU, Khmelnytskyj, 2012)

[28] State Statistics Service of Ukraine. Official site. Statistical information. Science and innovation. Scientific and innovative activity (1990 - 2019) (2020), http://www.ukrstat.gov.ua/

[29] T. Davydiuk, Analiz pidkhodiv do otsinky liudskoho kapitalu yak obiekta bukhhalterskoho sposterezhennia (Analysis of approaches to the assessment of human capital as an object of accounting observation) (DonNUET, Kryvyi Rih, 2017)

[30] C. Handy, Gods of Management: The Changing Work of Organizations (Macmillan, New York, 1979)

[31] T. Kravchenko, State and regions. Series: Economics and Business 6, 142 (2013)

[32] A. Zlenko, O. Isaikina, University Economic Bulletin 46, 115 (2020)

[33] J. Fitzenz, The ROI of Human Capital. Measuring the Economic Value of Employee Performance (AMACOM, New York, 2009)

[34] O. Zakharova, N. Podluzhna, Socio-labor relations: theory and practice 2, 90 (2016)

[35] G. Zhavoronkova, V. Zhavoronkov, D. Sokovnina, L. Melnyk, M. Gomeniuk, Intellectucal capital of enterprises of APC in the regional innovative system (Vydavets Sochinskyj, Uman, 2012)

[36] A. Zinchenko, M. Saprykina, CSR development in Ukraine: 2010-2018 (Yuston, Kyiv, 2017)

[37] E. Hontz, O. Okuniev, M. Saprykina, Company transparency index 2019 - Ukraine (2020), https://drive.google.com/file/d/ 1CjQ-gDivH30WDx-QSZysDsUFCtJHeeoe/view

[38] Biznes, shcho zminiuie krainu (Business that changes the country) (2019), https://project.liga. net/projects/business_changing/\#17

[39] Best practices in corporate social responsibility have been identified in ukraine (2017), https://cutt. ly/hlx10mX 